\title{
Joint effects of nine antidepressants on Raphidocelis subcapitata and Skeletonema marinoi : a matter of amine functional groups
}

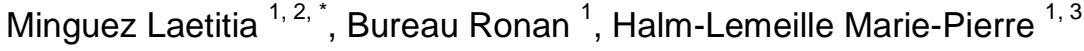

${ }^{1}$ CERMN, UFR des Sciences Pharmaceutiques, UPRES EA4258 - FR CNRS INC3 M - SF 4206

ICORE, Université de Caen Basse-Normandie, Bd Becquerel, Caen cedex 14032, France

${ }^{2}$ Université de Lorraine, CNRS UMR 7360, Laboratoire Interdisciplinaire des Environnements

Continentaux (LIEC), Campus Bridoux, Rue du Général Delestraint, Metz 57070, France

${ }^{3}$ Ifremer, LER, Station de Port en Bessin, Avenue du Général de Gaulle BP 32, Port en Bessin 14520,

France

*Corresponding author : Laetitia Minguez, email address : laetitia.minguez@univ-lorraine.fr

\begin{abstract}
:
Antidepressants are among the most prescribed pharmaceuticals throughout the world. Their presence has already been detected in several aquatic ecosystems worldwide and their effects on non-target organisms justify the growing concern of both the public and regulatory authorities. These emerging pollutants do not occur as isolated compounds but rather as multi-component mixtures, which may lead to increased adverse effects compared to individual compounds. Freshwater and marine algae seem particularly sensitive to pharmaceuticals, including antidepressants. Studies assessing the toxicity of antidepressant mixture to algae focused mainly on binary mixtures of selective serotonin reuptake inhibitors. In the present experiment, the freshwater algae Raphidocelis subcapitata (formerly known as Pseudokirchneriella subcapitata) and the marine diatom Skeletonema marinoi were exposed to equitoxic mixtures of 9 antidepressants (fluvoxamine, fluoxetine, sertraline, duloxetine, venlafaxine, clomipramine, amitriptyline, and citalopram) at different concentrations. The growth inhibition was measured.
\end{abstract}

Results showed that the toxicity of this mixture was higher than the effects of each individual component, highlighting simple additivity or synergistic effects, whereas tested concentrations were below the $10 \%$ inhibition concentration (IC10) of each compound. Moreover, the QSAR analysis highlighted that antidepressants would act through narcosis (non-specific mode of action) towards the two species of algae. However, more specific effects can be observed by differentiating compounds with a primary/secondary amine from those with a tertiary amine. These mixture effects on algal species have to be assessed, especially since any impacts on phytoplankton could ultimately impact higher trophic levels (less food, secondary poisoning). 


\section{Highlights}

- Additivity and synergism were observed even at concentrations below the $\mathrm{IC}_{10}$. Observed mixture toxicity did not always fit with the CA model. Polar narcosis would be the mode of action of primary/secondary amines to Raphidocelis subcapitata. A more specific mode of action is hypothesized to Skeletonema marinoi. - Tertiary amines would act through non-polar narcosis to both algae species.

Keywords : green algae, diatom, mixture, pharmaceutical, QSAR 


\section{Introduction}

Pharmaceuticals are one of the most frequently detected emerging contaminants in surface waters (Fent et al 2006; Santos et al 2010). Almost three thousand compounds are currently used belonging to diverse therapeutic families. Their increasing consumption and the limited efficiency of sewage treatment plants to completely remove them lead to their continuous emission into surface waters (Fent et al 2006; Santos et al 2010). Their widespread occurrence in aquatic ecosystems raises the question whether pharmaceuticals might pose a risk for exposed non-target organisms (Fent et al 2006). Within the past decade, the number of scientific publications about the assessment of the ecological impact of pharmaceuticals on freshwater and marine ecosystems has significantly increased, concomitantly with improvements in analytical methods and abilities to detect trace levels (e.g. Daughton and Ternes, 1999; reviews by Brooks and Hugett, 2012; Kummerer, 2008; Santos et al 2010). However, knowledge gaps still remain especially concerning marine organisms and mixture toxicities though the usual exposure in the environment is towards pharmaceutical mixtures. In 2004, Henry et al already underlined the importance to investigate the effects of mixtures in future research. Ten years later, in his review Backhaus (2014) reported that knowledge on the impact of pharmaceutical mixtures on aquatic organisms, especially marine organisms, was still severely lacking.

Several types of pharmaceuticals already raise concern due to their toxic effects on aquatic organisms, as highlighted by Minguez et al (2016) in their risk assessment study. Antidepressants are one of these drug classes (Fong and Ford, 2014; Minguez et al 2016). They are used in the treatment of depression and other psychiatric disorders in human by modifying neurotransmission, but the good evolutionary conservation of their therapeutic targets means that they may have physiological effects on non-target aquatic organisms too (Fong and Ford, 2014). An antidepressant classification exists based on their mechanisms of action, and three groups are defined: (1) monoamine oxidase inhibitors (MAOI), (2) selective serotonin reuptake 
inhibitors (SSRI) and (3) serotonin-norepinephrine reuptake inhibitors (SNRI). However, the chemical structure of all organic compounds is also an important parameter to understand their behavior in organisms (McKinney et al, 2000). This is particularly true for organisms not possessing neurotransmitters, like algae, and thus, for which the current classification of antidepressants is irrelevant.

Antidepressants have all in common the presence of an amine functional group participating in the interaction with cellular membranes (Minguez et al 2014), and playing a role both in their physicochemical properties, such as basicity or steric dimension, and in their biological properties by providing a cationic center helping in mimicking or in interfering with biogenic amine neurotransmitters. However, these general properties can change depending on amine subclass (Sánchez and Hyttel, 1999). Antidepressants can thus be separated into primary amines like fluvoxamine, secondary amines like fluoxetine, sertraline and paroxetine, and tertiary amines like venlafaxine and citalopram (Wishart et al 2006). It has to be noted that antidepressants are mainly secondary or tertiary amines (Sánchez and Hyttel, 1999). Despite the key role played by the amine functional group in the biological activity of antidepressants, to our knowledge no studies have tried to link ecotoxicity of antidepressants to aquatic organisms and these subclasses of amines.

Most of antidepressants display octanol-water partition coefficients $\left(\log K_{O W}\right)$ higher than or equal to 3 (Wishart et al 2006) and thus have the ability to interact with lipid membranes in organisms and bioaccumulate along the food web (Christensen et al, 2007; Besse and Garric, 2010). At the basis of aquatic ecosystems, primary producers such as algal species, seem to accumulate and be particularly sensitive to antidepressants (Brooks et al, 2003; Christensen et al, 2007; Johnson et al, 2007; Minguez et al 2015, 2016). Indeed, according to the classification of EU directive 93/67/EEC (EU, 2003) which classified substances based on their effective concentration affecting $50 \%$ of an endpoint $\left(\mathrm{EC}_{50}\right)$, studied antidepressants, mostly SSRI 
compounds, would be considered from toxic to very toxic to algae (Brooks et al, 2003; Christensen et al, 2007; Johnson et al, 2007; Minguez et al, 2016). Consequently, any disruption of primary producer compartment may have cascading adverse effects on higher trophic levels, and assessing pharmaceutical toxicity to algae is thus of ecological interest.

The aims of the present study was thus (1) to investigate the joint effects of nine antidepressants on growth of two algal species, i.e. the freshwater green alga Raphidocelis subcapitata (formerly known as Pseudokirchneriella subcapitata) (Guiry, 2017) and the marine diatom Skeletonema marinoi, by applying the Concentration Addition concept (CA) proven to be powerful in predicting mixture toxicity of compounds with similar mode or mechanism of action (e.g. Christensen et al 2007; Henry and Black, 2007); and (2) to identify the compounds driving mixture effects. For that, we exposed the two algal species for 72 hours to different antidepressant mixtures (i.e. a mixture of nine antidepressants, a mixture of primary and secondary amines, and a mixture of tertiary amines) according to guidelines of standardized bioassays.

\section{Materials and Methods}

\subsection{Tested compounds}

The nine antidepressants we used for the bioassays were the primary amine, fluvoxamine maleate; secondary amines, fluoxetine $\mathrm{HCl}$, sertraline $\mathrm{HCl}$, paroxetine $\mathrm{HCl}$ and duloxetine $\mathrm{HCl}$; and tertiary amines, venlafaxine $\mathrm{HCl}$, clomipramine $\mathrm{HCl}$, amitriptyline $\mathrm{HCl}$, and citalopram $\mathrm{HBr}$ (Table 1). All nine were supplied in analytical grade by Kemprotec Limited ${ }^{\circledR}$ (Maltby, Middlsbrough, U.K.). All these antidepressants have been detected in the environment (Roig and D'Aco, 2016).

\subsection{Algal growth inhibition assays}


Freshwater algal tests were conducted following the NF EN ISO 8692 (ISO, 2012) guideline using the microalga Raphidocelis subcapitata AC152 obtained from Algobank (Caen, France). Marine algal tests were performed following the NF EN ISO 10253 (ISO, 2006) guideline using the diatom Skeletonema marinoi AC174 provided by Algobank (Caen, France). All algal growth inhibition tests were conducted at $21 \pm 1{ }^{\circ} \mathrm{C}$ with continuous shaking at $100 \mathrm{rpm}$ and continuous white light $\left(84 \mu \mathrm{mol}\right.$ photons $\left./ \mathrm{m}^{2} / \mathrm{s}\right)$. Stock solutions were prepared by directly dissolving test compounds in Lefevre-Czarda medium supplemented with trace elements for freshwater assays (AFNOR, 1980) or in f/2 medium (Guillard and Ryther, 1962) for marine assays. Test concentrations were obtained by serial dilutions from stock solutions. To ensure the exposure of alga to the right concentrations, concentrations were quantified according to the method detailed in Minguez et al (2015). Measurements were done only on t0-solutions due to a low volume of solutions available at the end of the exposure. As measured concentrations were within the $95 \%$ confidence intervals of respective IC $x$ (Table 2; Minguez et al, 2016) and also in the 20-25\% range of nominal concentrations, we considered that $R$. subcapitata and $S$. marinoi were exposed to the wanted concentrations. Moreover, under test conditions for algae, antidepressants seem to be stable (Christensen et al 2007). The toxicity tests were performed in 96-well cell culture plates, sealed with a polyester film to avoid evaporation and to isolate each well from the other. Each substance, the medium and the algal inoculums were mixed to obtain an initial algal concentration of $10^{4}$ cells $/ \mathrm{mL}$ in $0.21 \mathrm{~mL}$ of bioassay volume. At least three technical replicates were used per concentration, and the exposure was repeated three times (i.e. biological replicates). The cell density was measured after $72 \mathrm{~h}$ of exposure. The results were quantified as average growth rates calculated from cell numbers based on measurements of chlorophyll fluorescence (680 nm, TECAN Infinite ${ }^{\circledR}$ M200 microplate reader). The percentages of inhibition of average specific growth relative to controls were calculated for each concentration. All the controls met the acceptability criteria (i.e. biomass concentration in 
the controls increased by a factor of at least 16 within the test period, and the coefficient of variation of average growth in replicate control cultures did not exceed $15 \%$ ).

\subsection{Calculation of effect concentrations and prediction of mixture toxicity}

Non-linear regressions using the Hill equation allowed the calculation of the concentrations inducing $5,10,20,50$ or $80 \%$ of growth inhibition (i.e. $\mathrm{IC}_{5}, \mathrm{IC}_{10}, \mathrm{IC}_{20}, \mathrm{IC}_{50}$ and $\mathrm{IC}_{80}$ respectively). These regressions were obtained using the Excel® macro REGTOX (Vindimian 2012) and are shown in Figure S1. The mathematical form of the Hill model used by the macro Excel® Regtox is:

$$
f(x)=x^{n H} /\left(x^{n H}+E C_{50}^{n H}\right)
$$

where $\mathrm{nH}$ is the Hill coefficient and $\mathrm{EC}_{50}$ is the concentration leading to $50 \%$ of effects. To assess mixture toxicities, algae were exposed to equitoxic mixtures, where each component in the mixture was present at the same fraction of their own individual toxicity. Ninth of the calculated inhibition concentrations $\left(\mathrm{IC}_{5} / 9, \mathrm{IC}_{10} / 9, \mathrm{IC}_{20} / 9, \mathrm{IC}_{50} / 9\right.$ and $\left.\mathrm{IC}_{80} / 9\right)$ were used. This implies different molar ratios at each tested concentration, since all antidepressants have different profiles of toxicity (Figure S1). Table 2 shows each inhibition concentrations. If the exposure to the mixture follows the concept of concentration addition, theoretically the combined effect of the nine antidepressants would add up to a total effect of 5, 10, 20, 50 and $80 \%$ respectively (Cleuvers, 2004).

Different theoretical indices of mixture toxicity can be found in the literature and apply to quantitative assessment of the deviation of data from the CA model (Altenburger et al, 2003). We analyzed our toxicity data by the sum of toxic units (STU). A toxic unit (TU) is defined as the concentration of a compound present in the mixture with a total effect of $x \%$ divided by its individual concentration that would alone cause the same $x \%$ effect. All individual TU values are then summed to obtain the STU parameter. To avoid false positives, the STU limits 
distinguishing a synergistic effect from a simple addition was set at 0.8 (Altenburger et al, 2003). Thus, $0.8 \leq \mathrm{STU} \leq 1.2$ indicate perfect fit to the applied model and STU $<0.8$ indicate underestimation of mixture toxicity, and STU > 1.2 indicate antagonism.

To explain the toxicity of the 9-compound mixture, first we used a component-based approach where antidepressants were tested as single compound at the same concentrations as in the mixture. Then, we separated compounds in two groups depending on their amine functions (i.e. presence of primary or secondary amine $v s$ a tertiary amine function) (Table 1). The toxicity of these two groups of compounds was assessed at the same concentrations as previously for the mixture of nine compounds.

\subsection{QSAR analysis}

To highlight the potential mode of action of the antidepressants in mixture, we used singleparameter quantitative structure activity relationship (QSARs) equation based on the octanolwater partition coefficient $\left(\log K_{\mathrm{Ow}}\right)$. Prior the regression analysis, the toxic concentrations $\left(\mathrm{IC}_{50}\right)$ of individual compounds were converted to molar concentrations, and experimental $\log K_{\text {ow }}$ values of each tested compound were retrieved from drugbank (https://www.drugbank.ca/). Linear regressions were calculated using MS-Excel. The quality of the final linear regression was assessed by the squared coefficient of correlation $\left(\mathrm{r}^{2}\right)$, the standard error of the regression (s), Fisher's criterion (F) and the p-value.

\section{Results}

\subsection{Toxicity assessment}

A mixture of nine antidepressants was screened for growth inhibition of the freshwater algae Raphidocelis subcapitata (Figure 1A) and the marine diatom Skeletonema marinoi (Figure 1B). There were little or no effects of the nine antidepressants by single-exposure (growth inhibition 
$\leq 30 \%)$ up to $\mathrm{IC}_{80} / 9$. For both species, the effect of the nonary mixture was above the prediction using the CA concept (Figure 1A, B). Calculations of sums of TU (i.e. STU) were done at 20\% growth inhibition, since $\mathrm{IC}_{20}$ is considered as equivalent to the lowest observed effect concentration (LOEC). STU calculations led to the same conclusion; the mixture of nine antidepressants may be defined by a synergistic effect to $R$. subcapitata and $S$. marinoi (i.e. STU < 0.8) (Table 3). Tested compounds displayed a stronger toxicity to the two algae species in mixture (shift from simple additive effects $>20 \%$ in Table 3 and lower $\mathrm{IC}_{\mathrm{x}}$ in mixture, Table 2).

The two algal species were also exposed to two other mixtures taking into account the amine subclass of each antidepressant (Figure 2A, B): either having primary and secondary amines or having tertiary amines. At the three lowest concentrations, the two amine mixtures were not toxic to $R$. subcapitata, meaning that both amine subclasses were needed to induce the observed toxicity of the 9 -antidepressant mixture (Figure $2 \mathrm{~A}$ ). At the $\mathrm{IC}_{50} / 9$, the mixture of primary and secondary amines is slightly more toxic than the one composed by tertiary amines. At the highest concentration, both mixtures of amines had the same effect on algal growth with almost $100 \%$ inhibition. According to STU calculations at $20 \%$ of growth inhibition for the two mixtures, CA model cannot be rejected (Table 3A). The marine diatom $S$. marinoi responded differently to amine mixtures (Figure 2B). At the three lowest concentrations, the toxicity of tertiary amines followed the toxicity pattern of the nonary mixture (i.e. same effect on growth inhibition). At $\mathrm{IC}_{50} / 9$, the tertiary-amine mixture remained more toxic than the mixture composed of antidepressants with primary or secondary amines. Like for R. subcapitata, the growth inhibition was almost $100 \%$ for the two amine mixtures at the highest concentration. STU calculations also illustrated the different toxicity profiles of the two amine mixtures, with in both cases suggesting the rejection of CA model (Table 3B). STU for the mixture of 
primary/secondary amines indicated antagonistic effects (i.e. STU > 1.2), whereas STU for the mixture of tertiary amines defined strong synergistic effects (i.e. STU $<<0.8$ ).

\subsection{QSAR analysis}

The linear relationship between the ecotoxicity $\left(\log \mathrm{IC}_{50}\right.$ in $\left.\mathrm{M}\right)$ to $R$. subcapitata of all the antidepressants and $\log \mathrm{K}_{\mathrm{OW}}$ showed a quite low correlation $\left(\mathrm{r}^{2}<0.8\right.$, equation 1$)$ (Figure $\mathrm{S} 2$ A).

$\log \left(\mathrm{IC}_{50}\right)=-0.62( \pm 0.25) \log \mathrm{K}_{\mathrm{OW}}-2.99( \pm 1.03)\left(\mathrm{r}^{2}=0.47, \mathrm{~s}=0.60, \mathrm{n}=9, \mathrm{~F}=6.21, \mathrm{p}=0.041\right)$

However, by separating the compounds according to their amine functions, the two considered parameters became strongly correlated (equations 2 and 3, Figure S2 B, C). The main difference between the two equations was the higher intercept value for primary and secondary amine (equation 2).

$\log \left(\mathrm{IC}_{50}\right)=-0.45( \pm 0.11) \log \mathrm{K}_{\mathrm{Ow}}-4.12( \pm 0.45)\left(\mathrm{r}^{2}=0.84, \mathrm{~s}=0.15, \mathrm{n}=5, \mathrm{~F}=15.92, \mathrm{p}=\right.$ $0.028)(2)$

$\log \left(\mathrm{IC}_{50}\right)=-0.79( \pm 0.15) \log \mathrm{K}_{\mathrm{Ow}}-1.81( \pm 0.66)\left(\mathrm{r}^{2}=0.92, \mathrm{~s}=0.31, \mathrm{n}=4, \mathrm{~F}=24.59, \mathrm{p}=\right.$ $0.038)(3)$

These two relationships (observed toxicities) can be compared with QSAR-predicted baseline toxicities calculated according to equation 17 from Villain et al $(2014)\left(\log \left(1 / \mathrm{IC}_{50}\right.\right.$ in $\left.\mathrm{M}\right)=0.45$ $\left.\log K_{\text {ow }}+3.08\right)($ Figure S2 B, C). Primary / secondary amines displayed higher toxicity (i.e. differences between the two curves higher than 1, Figure S2 B), whereas toxicity of tertiary amines can be predicted by baseline toxicity (differences between the two curves less than 1, Figure S2 C).

For Skeletonema marinoi, by considering all the antidepressants together or only the primary/secondary amines, a low or no correlation between $\log \left(\mathrm{IC}_{50}\right)$ and $\log \mathrm{K}_{\mathrm{Ow}}$ was observed 
(equations 4 and 5, Figure S2 D, E); whereas a strong correlation was found between the toxicity of tertiary amines and their octanol-water partition coefficients (equation 6, Figure S2 F).

$\log \left(\mathrm{IC}_{50}\right)=-0.88( \pm 0.36) \log \mathrm{K}_{\mathrm{OW}}-3.11( \pm 1.41)\left(\mathrm{r}^{2}=0.46, \mathrm{~s}=0.86, \mathrm{n}=9, \mathrm{~F}=5.98, \mathrm{p}=\right.$ 0.044) (4).

$\log \left(\mathrm{IC}_{50}\right)=-0.13( \pm 0.61) \log \mathrm{K}_{\mathrm{OW}}-6.38( \pm 2.45)\left(\mathrm{r}^{2}=0.016, \mathrm{~s}=0.82, \mathrm{n}=5, \mathrm{~F}=0.05, \mathrm{p}=\right.$ $0.84)(5)$.

$\log \left(\mathrm{IC}_{50}\right)=-1.27( \pm 0.26) \log \mathrm{K}_{\mathrm{OW}}-1.11( \pm 1.12)\left(\mathrm{r}^{2}=0.92, \mathrm{~s}=0.52, \mathrm{n}=4, \mathrm{~F}=22.84, \mathrm{p}=\right.$ $0.041)(6)$

\section{Discussion}

The joint toxic effects of pharmaceutical mixtures remain today an important issue for a more reliable hazard and risk assessment. Algal species are good biological models to assess mixture toxicities, since they are important components in aquatic ecosystems and any impacts on these primary producers may lead to knock-on effects on higher trophic levels. In the present study, we highlighted additive and even synergistic effects of a mixture of nine antidepressants to a freshwater green alga $R$. subcapitata and a marine diatom S. marinoi, whereas tested concentrations were below $\mathrm{IC}_{10}$ of each compound. The $\mathrm{IC}_{10}$-values are considered as equivalent to no observed effect concentrations (NOEC) (Chapman et al, 1996; Warne and van Dam, 2008). The QSAR analysis highlighted at least for tertiary amine a non-specific MOA for the two algae species.

When applying a whole-mixture approach with a known composition as defined by Backhaus (2014), the assessment of the toxicity of each mixture component is one step in the understanding of the overall toxicity. The common pattern for pharmaceutical mixtures is to display a higher toxicity than their individual components, independently of the chemical nature of these components, the exposed organisms or the studied endpoints (reviewed by Backhaus, 
2014). This toxicity is precisely the origin of environmental concerns. Indeed, several authors report this higher toxicity towards aquatic organisms from binary to more complex mixtures of dissimilarly acting pharmaceuticals (e.g. Backhaus et al, 2000a; Cleuvers, 2003; DeLorenzo and Fleming, 2008; Dietrich et al, 2010; Fent et al, 2006; Flaherty and Dobson, 2005) as well as mixtures of compounds with similar mode of actions (e.g. Backhaus et al, 2000b; Christensen et al, 2007; Henry and Black, 2007).

Herein, we investigated the toxicity of the whole mixture as a combination of the individual effects of 9 antidepressants, and by grouping compounds according to their amine function. The higher toxicity of the whole mixture compared to effects of individual components can be defined either by simple addition or by synergism. Since the mixture was composed by nine antidepressants sharing similar pharmacological mode of action, a concentration addition model (CA) was expected (Cleuvers, 2003). However, for the two algal species, observed $\mathrm{IC}_{\mathrm{x}} \mathrm{s}$ for the mixture were well below those expected according to CA model. This is translated by STU < 0.8 suggesting synergistic effects. Deviations from CA-predicted mixture toxicities have been already reported in the literature but mainly for binary mixtures of pharmaceuticals. For example, synergistic effects to $R$. subcapitata have been observed for mixtures of antibiotics (Christensen et al, 2007; Eguchi et al, 2004) or binary combinations of anticancer drugs (Brezovšek et al, 2014). However, most of the studies performed with $R$. subcapitata exposed to antidepressant mixture concluded that CA cannot be rejected (Christensen et al, 2007; Henry and Black, 2007; Johnson et al 2007). This study mainly focused on mixture of SSRIs, and especially ones with secondary amines. By grouping compounds according to their amine function, CA-model fitted well with observed results. This result suggests that each compound within a sub-group of amines share an identical mode of action. Studies assessing the toxicity of pharmaceutical mixtures on marine algae are still scarce, and tested mixtures were often composed by dissimilarly acting compounds. In these cases, CA model was a good predictor of 
mixture toxicities (Backhaus et al, 2011; DeLorenzo and Fleming, 2008; Petersen et al, 2014). Herein, CA is rejected for all the studied mixtures on $S$. marinoi, suggesting that the amine function is not the only parameter explaining antidepressant toxicity. Further studies are thus needed to better understand the observed synergistic effects of antidepressants on S. marinoi, especially effects of tertiary amines.

One further step in the understanding of mixture toxicities is to identify which compound(s) is/are the driver(s) of the overall mixture toxicity. Interactions between several pharmaceuticals can be seen as either toxicokinetic interactions (e.g. interactions in uptake or metabolism of the compounds) and/or toxicodynamic interactions (i.e. interactions at the target site). The risk of interactions between several compounds is then a function of both the number of compounds and their chemical structures. More antidepressants are used at the same time, more the risk of interactions between them increases. Moreover, the chemical structure of the compounds influences both their toxicokinetics and toxicodynamics, which can lead to different effects. However, the specific mechanism of toxicity of antidepressants to algae is not yet known. That's why we decided to gather antidepressants according to their amine functional group. Indeed, this amine group plays a key role in the physico-chemical properties of antidepressants (Sánchez and Hyttel, 1999). To our knowledge, this is the first time that amine functional groups are considered in mixture toxicities.

Patterns of toxicity towards the two algal species can be described by three phenomena taking place (1) at the three lowest concentrations, (2) at $\mathrm{IC}_{50} / 9$ and (3) at the highest concentration. Results obtained on $R$. subcapitata showed a coalition of primary/secondary amines and tertiary amines to lead to the overall mixture toxicity at the three lowest tested concentrations, since neither the primary/secondary amine mixture nor the tertiary amine mixture were toxic alone. Between $\mathrm{IC}_{20} / 9$ and $\mathrm{IC}_{50} / 9$, a threshold was reached and both amine mixtures displayed significant toxicities producing an increase in the overall mixture toxicity. 
At the highest concentration, whatever the mixture considered, algal growth was almost completely inhibited. In principle, organic compounds can act as narcotics (non-specific MOA) and accumulate in membranes. QSAR equations using logKow are often used to predict this minimum toxicity, and two MOAs are distinguished, i.e. the so-called non-polar and polar narcosis, the latter being slightly more toxic (Verhaar et al 1992). Herein, we found a strong correlation between ecotoxicity of antidepressants to $R$. subcapitata and $\log \mathrm{K}_{\mathrm{OW}}\left(\mathrm{r}^{2}>0.8\right.$ in equation 2 and 3). As the observed toxicities are given as concentrations in the media, they depend on both the uptake of antidepressants by algae and the affinity of the tested compounds to their site of action in algae. Knowledge about toxicokinetics of antidepressants is not yet available in algae. Thus, the observed strong correlation between $\mathrm{IC}_{50}$ and $\log \mathrm{K}_{\mathrm{OW}}$ suggests either narcotic MOA or a similar MOA with a passive and lipophilicity-driven uptake. By comparing observed toxicities with QSAR-predicted baseline toxicities, relationships between $\mathrm{IC}_{50}$ and $\log \mathrm{K}_{\mathrm{Ow}}$ indicate narcosis for tertiary amines and a specific MOA for primary / secondary amines. Mechanistic studies are needed to fully understand the difference of MOAs between the two types of amines. According to the biopharmaceutical drug disposition classification system (BDDCS) (Benet et al, 2011), all antidepressants belong to classes 1 or 2 for compounds with high permeability. Indeed, they display structural characteristics, i.e. lipophilic aromatic group, an amino group and an alkyl chain, helping to reach an optimum interaction with biological membranes. However, the presence of a cell wall and the composition of cell membranes in algae, which differ from cells in higher animals, may influence the strength of the interaction. Thus, the classification of antidepressants for algae might be different. Some antidepressants can have a more specific MOA depending on their ability to cross biological membranes. In our study, the toxicity level of the two types of amines differed as illustrated by equation intercepts. The higher intercept value and a great difference between baseline QSAR-expected and observed toxicity for primary and secondary amines 
(|intercept $\mid=4.12)$ suggests a stronger toxicity, and so an effect through a polar narcosis. Fluoxetine is one of the most studied of these secondary amines for which physiological modes of action have been highlighted for different model organisms (e.g. Minguez et al 2014; Neuwoehner et al 2009). For example, by exposing $R$. subcapitata to this antidepressant, Neuwoehner et al (2009) have shown that this secondary amine exerted baseline toxicity but was also able to disturb the membrane-protein interfaces in a non-specific way which added to the overall effect. In contrast, tertiary amines would act through a non-polar narcosis (|intercept| $=1.81$ ). The QSAR equations that we obtained were based on few compounds ( 4 or 5 depending on the type of amines), thus one could wonder whether these equations are reliable to identify antidepressant modes of action. Nonetheless, Villain et al (2014) found similar equations for the two kinds of narcosis by using a broader set of toxicity data for 336 chemicals with also non-specific MOA and quantile regression analyses, which support our findings. Toxicity pattern to $S$. marinoi differed from $R$. subcapitata. Indeed, at the three lowest concentrations, the overall mixture toxicity was only related to the effects of the four tertiary amines. From QSAR analysis on these amines, a non-polar narcosis was recorded for this antidepressant group (equation 6, strong correlation between $\log \left(\mathrm{IC}_{50}\right)$ and $\log \mathrm{K}_{\mathrm{ow}}$, and low intercept). Moreover, the absence of correlation between primary/secondary amine toxicities and their LogKow suggest a more specific MOA.

Our results suggest that the MOA of antidepressants towards algae would be narcosis associated or not to a more specific MOA, but the toxicity patterns were different between the two species. The compounds were 5 to 10 -fold more toxic to $S$. marinoi than to $R$. subcapitata. The $\mathrm{pH}$ of culture media can be an important parameter influencing the toxicokinetics (uptake, concentration, distribution and elimination) of pharmaceuticals (Neuwoehner and Escher, 2011). The $\mathrm{pH}$ of the LC medium used to grow $R$. subcapitata was 7 whereas the $\mathrm{pH}$ of the $\mathrm{f} / 2$ medium used for $S$. marinoi was 8 . This slight difference is enough to increase the neutral 
fraction of antidepressants and therefore to facilitate their entry into algal cells (Neuwoehner and Escher, 2011). Moreover, antidepressants as basic lipophilic compounds are also known to be trapped by acidic subcellular compartments (Daniel and Wójcikowski, 1997). Unlike the green alga $R$. subcapitata, the exoskeleton of the diatom $S$. marinoi, called the frustule, consists in two valves of silica and organic matter. During cell cycle, silica formation imposes special steps consisting of forming new silica valves inside a specialized vesicle, the silicon deposition vesicule (SDV) (Vrieling et al 1999). This SDV is assumed to be acidic (Gordon and Drum, 1994). Due to their physico-chemical properties antidepressants could be trapped in the SDV. Consequently, any disturbance of the silica fixation in the SDV will prevent the formation of two daughter cells, and growth will be inhibited. Samorì et al. (2011) have observed a similar difference of sensitivity between two diatoms S. marinoi and Phaeodactylum tricornutum exposed to 1-butyl-3- methylimidazolium chloride, the latter species being more sensitive. Like antidepressants, this compound is associated to a positive formal charge. In their publication, authors hypothesized that difference of sensitivity would be related to silica, P. tricornutum requiring silica to grow.

In this study, algae were exposed to equitoxic mixtures leading to significant growth inhibition even at the lowest tested concentration. Although pollutants are rarely all present in aquatic ecosystems at concentrations with the same effects, additive and synergistic effects may be expected. Any impacts on phytoplankton populations could ultimately impact higher trophic levels (less food, secondary poisoning). One needs to focus especially on marine ecosystems, since marine diatoms seem more sensitive and more specific MOAs are possible than in freshwater ones. As recommended by Ankley et al (2007), we should read across the therapeutic MOA of pharmaceuticals to understand their MOA in non-target organisms. One possibility will be to take into account chemical structures, since in a sense each functional group of a compound plays a role in its toxicokinetics and toxicodynamics. 


\section{Acknowledgments}

This work is a contribution to the Pharm@Ecotox project (reference: ANR-10-CESA-0013) funded by the French National Research Agency (ANR, fr: Agence Nationale de la Recherche). We are grateful to Sharon Kruger for English language editing. We would also like to thank the two anonymous reviewers for their helpful and constructive comments that greatly improved the manuscript. 


\section{References}

AFNOR, 1980. Norme expérimentale NT90-304. Association Française de Normalisation ; Paris, France. AFNOR, Détermination de l'inhibition de croissance de Scenedesmus subspicatus par une substance.

Altenburger R., Nendza M., Schüürmann G., 2003. Mixture toxicity and its modeling by quantitative structure-activity relationships. Environ. Toxicol. Chem. 22(8), 1900-1915.

Ankley G.T., Brooks B.W. Huggett D.B., Sumpter J.P., 2007. Repeating history: pharmaceuticals in the environment. Environ. Sci. Technol. 41, 8211-8217.

Backhaus T., 2014. Medicines, shaken and stirred: a critical review on the ecotoxicology of pharmaceutical mixtures. Phil. Trans. R. Soc. B 369, 20130585.

Backhaus T., Altenburger R., Boedeker W., Faust M., Scholze M., Grimme L.H., 2000a. Predictability of the toxicity of a multiple mixture of dissimilarly acting chemicals to Vibrio fischeri. Environ. Toxicol. Chem. 19, 2348-2356.

Backhaus T., Scholze M., Grimme L.H., 2000b. The single substance and mixture toxicity of quinolones to the bioluminescent bacterium Vibrio fischeri. Aquat. Toxicol. 49, 49-61.

Backhaus T., Porsbring T., Arrhenius Å., Brosche S., Johansson P., Blank H., 2011. Singlesubstance and mixture toxicity of five pharmaceuticals and personal care products to marine periphyton communities. Environ. Toxicol. 30, 2030-2040.

Benet L.Z., Broccatelli F., Oprea T.I., 2011. BDDCS applied to over 900 drugs. The AAPS J. 13(4), 519-547.

Besse J.P., Garric J., 2010. Environmental risk assessment and prioritization strategies for human pharmaceuticals, review and discussion. In: Roig B (Ed.) Pharmaceuticals in the 
environment: Current knowledge and need assessment to reduce presence and impact. IWA Publishing, London, UK. European Commission project n ${ }^{\circ} 36864$

Brezovšek P., Eleršek T., Filipič M., 2014. Toxicities of four anti-neoplastic drugs and their binary mixtures tested on the green alga Pseudokirchneriella subcapitata and the cyanobacterium Synechococcus leopoliensis. Water Res. 52, 168-177.

Brooks B.W., Foran C.M., Richards S.M., Weston J., Turner P.K., Stanley J.K., Solomon K.R., Slattery M., La Point T.W., 2003. Aquatic ecotoxicology of fluoxetine. Toxicol. Lett. 142 (3), $169-183$.

Brooks B.W., Hugett D.B., eds., 2012. Human pharmaceuticals in the environment: Current and future perspectives. Springer, New York, 302p.

Chapman P.M., Cardwell R.S., Chapman P.F., 1996. A warning: NOECs are inappropriate for regulatory use. Environ. Toxicol. Chem. 15:77-79.

Christensen A.M., Faaborg-Andersen S., Ingerslev F., Baun A., 2007. Mixture and singlesubstance toxicity of selective serotonin reuptake inhibitors toward algae and crustaceans. Environ. Toxicol. Chem. 26 (1), 85-91.

Cleuvers M., 2003. Aquatic ecotoxicity of pharmaceuticals including the assessment of combination effects. Toxicol. Lett. 142, 185-194.

Cleuvers M., 2004. Mixture toxicity of the anti-inflammatory drugs diclofenac, ibuprofen, naproxen, and acetylsalicylic acid. Ecotox. Environ. Safe. 59, 309-315.

Daniel W.A., Wójcikowski J., 1997. Contribution of lysosomal trapping to the total tissue uptake of psychotropic drugs. Pharmacol. Toxicol. 80, 62-68.

Daughton C.G., Ternes T.A., 1999. Pharmaceuticals and personal care products in the environment: agents of subtle change? Environ. Health Perspect. 107, 907-938. 
DeLorenzo M.E., Fleming J., 2008. Individual and mixture effects of selected pharmaceuticals and personal care products on the marine phytoplankton species Dunaliella tertiolecta. Arch. Environ. Contam. Toxicol. 54, 203-210.

Dietrich S., Ploessl F., Bracher F., Laforsch C., 2010. Single and combined toxicity of pharmaceuticals at environmentally relevant concentrations in Daphnia magna - A multigenerational study. Chemosphere 79, 60-66.

Eguchi K., Nagase H., Ozawa M., Endoh Y.S., Goto K., Hirata K., Miyamoto K., Yoshimura H., 2004. Evaluation of antimicrobial agents for veterinary use in the ecotoxicity test using microalgae. Chemosphere 57, 1733-1738.

EU, 2003. Technical guidance document in support of commission directive 93/67/EEC on risk assessment for new notified substances and commission regulation (EC) No. 1499/94 on risk assessment for existing substances. II. Environmental Risk Assessment. Office for official publications of the European Communities. http://europa.eu.int, Luxembourg.

Fent K., Weston A.A., Caminada D., 2006. Ecotoxicology of human pharmaceuticals. Aquat. Toxicol. $76(2), 122-159$.

Flaherty C.M., Dobson S.I., 2005. Effects of pharmaceuticals on Daphnia survival, growth and reproduction. Chemosphere 61, 200-207.

Fong P.P., Ford A.T., 2014. The biological effects of antidepressants on the molluscs and crustaceans: A review. Aquat. Toxicol. 151, 4-13.

Gordon R., Drum R.W., 1994. The chemical basis of diatom morphogenesis. Int. Rev. Cytol. $150,243-372$.

Guillard R.R.L., Ryther J.H., 1962. Studies of marine planktonic diatoms. I. Cyclotella nana Hustedt and Detonula confervacea Cleve. Can. J. Microbiol. 8, 229-239. 
Guiry M.D., 2017. AlgaeBase. In Guiry, M.D., Guiry, G.M., AlgaeBase: World-wide electronic publication, National University of Ireland, Galway. http://www.algaebase.org; searched on October 2017.

Henry T.B., Black M.C., 2007. Mixture and single-substance acute toxicity of selective serotonin reuptake inhibitors in Ceriodaphnia dubia. Environ. Toxicol. Chem. 26(8), 17511755.

Henry T.B., Kwon J.W., Armbrust K.L., Black M.C., 2004. Acute and chronic toxicity of five selective serotonin reuptake inhibitors in Ceriodaphnia dubia. Environ. Toxicol. Chem. 23, $2229-2233$.

ISO, 2006. Water quality - Marine algal growth inhibition test with Skeletonema costatum and Phaeodactylum tricornutum. ISO 10253:2006, p.19

ISO, 2012. Water quality - Fresh water algal growth inhibition test with unicellular green algae. ISO 8692:2012, p.21

Johnson D.J., Sanderson H., Brain R.A., Wilson, C.J., Solomon K.R., 2007. Toxicity and hazard of selective serotonin reuptake inhibitor antidepressants fluoxetine, fluvoxamine, and sertraline to algae. Ecotox. Environ. Safe. 67, 128-139.

Kummerer K., ed. (2008) Pharmaceuticals in the environment: Source, fate, effects and risks. 3rd edition, Springer, New York. 522p.

McKinney J.D., Richard A., Waller C., Newman M.C., Gerberick F., 2000. The practice of structure activity relationship (SAR) in toxicology. Toxicol. Sci. 56, 8-17.

Minguez L., Farcy E., Ballandonne C., Lepailleur A., Serpentini A., Lebel J.-M., Bureau R., Halm-Lemeille M.-P., 2014. Acute toxicity of 8 antidepressants: What are their modes of action? Chemosphere 108, 314-319. 
Minguez L., Ballandonne C., Rakotomalala C., Dubreule C., Kientz-Bouchart V., HalmLemeille M.-P., 2015. Transgenerational effects of two antidepressants (sertraline and venlafaxine) on Daphnia magna life history traits. Environ. Sci. Technol. 49(2): 1148-1155.

Minguez L., Pedelucq J., Farcy E., Ballandonne C., Budzinski H., Halm-Lemeille M.-P., 2016. Toxicities of 48 pharmaceuticals and their freshwater and marine environmental assessment in northwestern France. Environ. Sci. Pollut. Res. 23, 4992-5001.

Neuwoehner J., Escher B.I., 2011. The pH-dependent toxicity of basic pharmaceuticals in the green algae Scenedesmus vacuolatus can be explained with a toxicokinetic ion-trapping model. Aquat. Toxicol. 101, 266-275.

Neuwoehner J., Fenner K., Escher B.I., 2009. Physiological modes of action of Fluoxetine and its human metabolites in algae. Environ. Sci. Technol. 43, 6830-6837.

Petersen K., Heiaas H.H., Tollefsen, K.E., 2014. Combined effects of pharmaceuticals, personal care products, biocides and organic contaminants on the growth of Skeletonema pseudocostatum. Aquat. Toxicol. 150, 45-54.

Roig B., D’Aco V., 2016. Distribution of pharmaceutical residues in the environment. In: Hester R.E., Harrison R.M. (Eds.), Pharmaceuticals in the environment. Issues in Environmental Science and Technology No 41, The Royal Society of Chemistry, pp. 34-69.

Samorì C., Sciutto G., Pezzolesi L., Galletti P., Guerrini F., Mazzeo R., Pistocchi R., Prati S., Tagliavini E., 2011. Effects of imidazolium ionic liquids on growth, photosynthetic efficiency, and cellular components of the diatoms Skeletonema marinoi and Phaedactylum tricornutum. Chem. Res. Toxicol. 24, 392-401.

Sánchez C., Hyttel J., 1999. Comparison of the effects of antidepressants and their metabolites on reuptake of biogenic amines and on receptor binding. Cell. Mol. Neurobiol. 19(4), 467-489. 
Santos L.H.M.L.M., Araújo A.N., Fachini A., Pena A., Delerue-Matos C., Montenegro M.C.B.S.M., 2010. Ecotoxicological aspects related to the presence of pharmaceuticals in the aquatic environment. J. Hazard. Mater. 175 (1-3), 45-95.

Verhaar H.J.M., van Leeuwen J., Hermens J.L.M., 1992. Classifying environmental pollutants. Chemosphere 25, 471-491.

Villain J., Lozano S., Halm-Lemeille M.-P., Durrieu G., Bureau R., 2014. Quantile regression model for a diverse set of chemicals: application to acute toxicity for green algae. J. Mol. Model. 20:2508. DOI 10.1007/s00894-014-2508-x

Vindimian E. 2012. MSExcel Macro Regtox 7.06 Freely available from Eric Vindimian. IRSTEA, France. http://www.normalesup.org/ vindimian.fr_index.html (accessed March 2012).

Vrieling E.G., Gieskes W.W.C., Beelen T.P.M., 1999. Silicon deposition in diatoms: control by the $\mathrm{pH}$ inside the silicon deposition vesicle. J. Phycol. 35, 548-559.

Warne M. St J., van Dam R., 2008. NOEC and LOEC data should no longer be generated or used. Australas J Ecotoxicol 14:1-5.

Wishart D.S., Knox C., Guo A.C., Shrivastava S., Hassanali M., Stothard P., Chang Z., Woolsey J., 2006. DrugBank: a comprehensive resource for in silico drug discovery and exploration. Nucleic Acids Res. 34 (Database Issue), D668-D672. doi:10.1093/nar/gkj067 


\section{Figure Captions}

Figure 1. Effect on algal growth rate of nine antidepressants after exposure to single compounds or the mixture. Effect on the freshwater green algae Raphidocelis subcapitata (A) and on the marine diatom Skeletonema marinoi (B). The mixture toxicity predicted by the concentration addition model is indicated by a grey line.

Figure 2. Mixture toxicities to the freshwater green algae Raphidocelis subcapitata (A) and the marine diatom Skeletonema marinoi (B). Algae were exposed to a mixture of nine antidepressants (i.e. Mixture), to a mixture of antidepressants with primary and secondary amines (i.e. Amines I/II), or to a mixture of tertiary amines (i.e. Amines III). Mean \pm confidence intervals $95 \%$ 
Fig 1

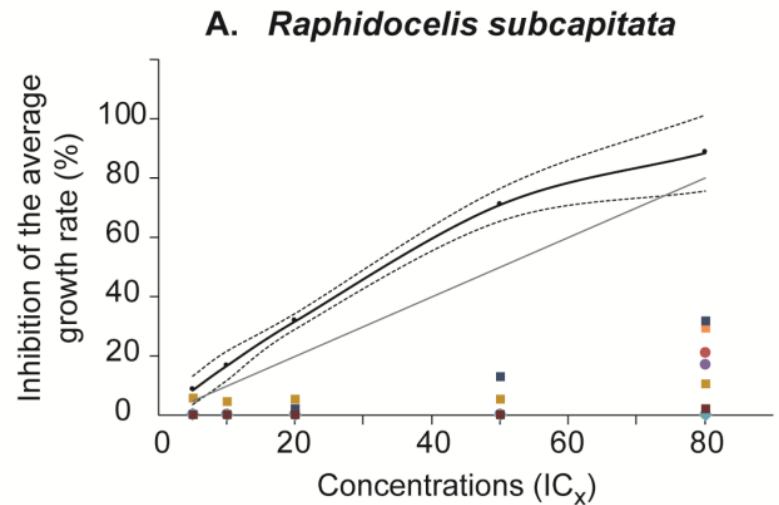

B. Skeletonema marinoi

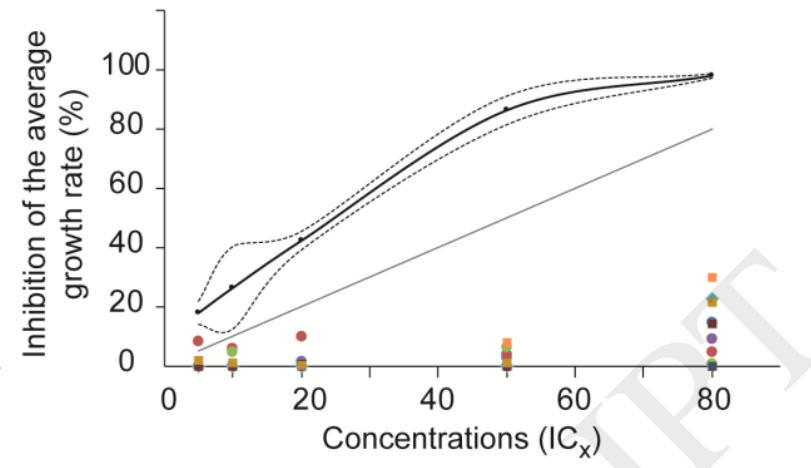

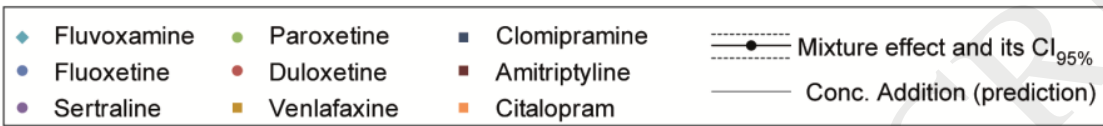


Fig 2

A. Raphidocelis subcapitata

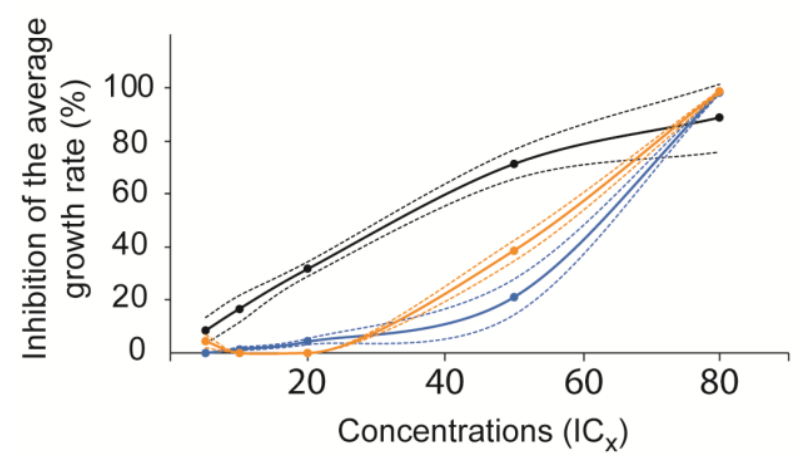

$\because \cdots \cdots$ Mixture

\section{B. Skeletonema marinoi}

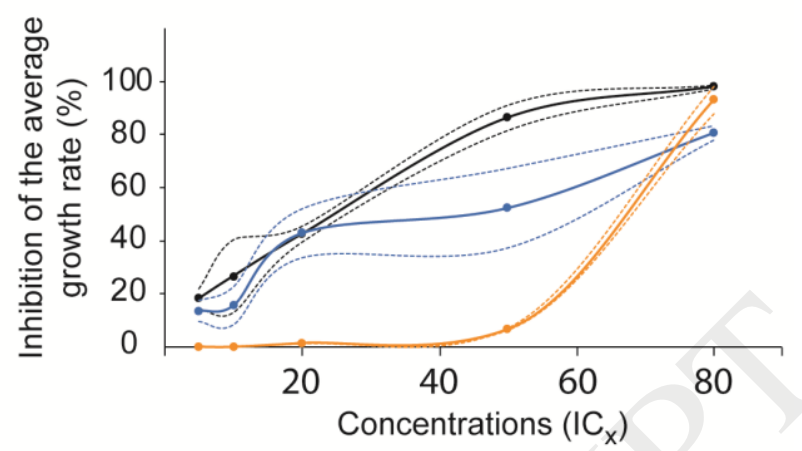

Amines I/II $\cong . \cdots \quad$ Amines III 
Table 1. Characteristics of tested antidepressants. The octanol-water partition coefficients LogKow were obtained from Drugbank database (experimental data).

Table 2. Concentrations of the nine antidepressants ( $\mu \mathrm{g} / \mathrm{L})$ leading to 5, 10, 20, 50 and $80 \%$ of growth inhibition $\left(\mathrm{IC}_{\mathrm{x}}\right)$, following freshwater and marine algal growth inhibition tests with Raphidocelis subcapitata and Skeletonema marinoi (ISO, 2006, 2012). The corresponding IC $_{\mathrm{x}}$ values in the mixture of 9 compounds are given between brackets.

Table 3. Predicted toxic units (TU) following Concentration Addition model and experimental TUs define for each antidepressant as the ratio between its observed $\mathrm{IC}_{20}$ in mixture and its $\mathrm{IC}_{20}$ when alone, for Raphidocelis subcapitata (A) and Skeletonema marinoi (B). Shift from simple additive effects is calculated as: $1-\left(\right.$ Experimental $\mathrm{TU}_{\mathrm{i}} /$ Predicted $\left.\mathrm{TU}_{\mathrm{i}}\right)$, when $\mathrm{CA}$ is rejected (i.e. for STU < 0.8: synergistic effects and, STU > 1.2: antagonistic effects). Positive shifts mean that compounds are more toxic in mixture than expected, and inversely in the case of negative shifts. 


\section{Tables}

Table 1. Characteristics of tested antidepressants. The octanol-water partition coefficients LogKow were obtained from Drugbank database (experimental data).

\begin{tabular}{lcccc}
\hline Compounds & CAS number & $\begin{array}{c}\text { Description } \\
\text { a }\end{array}$ & $\begin{array}{c}\text { Subclass of } \\
\text { amine }\end{array}$ & LogKow $^{\text {b }}$ \\
\hline Fluvoxamine & $61718-82-9$ & SSRI & Primary & 2.8 \\
Fluoxetine & $56296-78-7$ & SSRI & Secondary & 4.1 \\
Sertraline & $79559-97-0$ & SSRI & Secondary & 5.1 \\
Paroxetine & $78246-49-8$ & SSRI & Secondary & 3.6 \\
Duloxetine & $136434-34-9$ & SNRI & Secondary & 4.2 \\
Venlafaxine & $99300-78-4$ & SNRI & Tertiary & 2.8 \\
Clomipramin & $17321-77-6$ & TCA & Tertiary & 5.2 \\
e & $549-18-8$ & TCA & Tertiary & 4.9 \\
Amitriptyline & $59729-32-7$ & SSRI & Tertiary & 3.5 \\
Citalopram &
\end{tabular}

aSSRI: Selective serotonin reuptake inhibitor, SNRI: selective serotonin-norepinephrine reuptake inhibitor, TCA: Tricyclic antidepressant

bDrugbank database (august 2017): https://www.drugbank.ca/ 
Table 2. Concentrations of the nine antidepressants ( $\mu \mathrm{g} / \mathrm{L}$ ) leading to $5,10,20,50$ and $80 \%$ of growth inhibition $\left(\mathrm{IC}_{\mathrm{x}}\right)$, following freshwater and marine algal growth inhibition tests with Raphidocelis subcapitata and Skeletonema marinoi (ISO, 2006, 2012). The corresponding IC values in the mixture of 9 compounds are given between brackets.

\begin{tabular}{|c|c|c|c|c|c|c|c|c|c|c|}
\hline \multirow[b]{2}{*}{$\begin{array}{l}\text { Compo } \\
\text { unds }\end{array}$} & \multicolumn{5}{|c|}{ Raphidocelis subcapitata } & \multicolumn{5}{|c|}{ Skeletonema marinoi } \\
\hline & $\mathrm{IC}_{5}$ & $\mathrm{IC}_{10}$ & $\mathrm{IC}_{20}$ & $\mathrm{IC}_{50}$ & $\mathrm{IC}_{80}$ & $\mathrm{IC}_{5}$ & $\mathrm{IC}_{10}$ & $\mathrm{IC}_{20}$ & $\mathrm{IC}_{50}$ & $\mathrm{IC}_{80}$ \\
\hline $\begin{array}{l}\text { Fluvoxa } \\
\text { mine }\end{array}$ & $\begin{array}{l}237.3 \\
(26.7)\end{array}$ & $\begin{array}{l}340.9 \\
(33.5)\end{array}$ & $\begin{array}{l}505.0 \\
(43.3)\end{array}$ & $\begin{array}{c}988.7^{a} \\
(70.8)\end{array}$ & $\begin{array}{c}1935.7 \\
(148.0)\end{array}$ & $\begin{array}{l}45.0 \\
(4.7)\end{array}$ & $\begin{array}{l}57.0 \\
(5.4)\end{array}$ & $\begin{array}{l}73.8 \\
(6.3)\end{array}$ & $\begin{array}{c}114.5^{\mathrm{a}} \\
(8.3)\end{array}$ & $\begin{array}{l}177.9 \\
(11.8)\end{array}$ \\
\hline $\begin{array}{l}\text { Fluoxeti } \\
\text { ne }\end{array}$ & $\begin{array}{l}68.6 \\
(7.7)\end{array}$ & $\begin{array}{l}90.4 \\
(9.1)\end{array}$ & $\begin{array}{l}121.8 \\
(11.1)\end{array}$ & $\begin{array}{c}202.9^{a} \\
(16.2)\end{array}$ & $\begin{array}{l}338.2 \\
(28.3)\end{array}$ & $4.1(0.5)$ & $7.3(0.7)$ & $\begin{array}{l}13.9 \\
(1.0)\end{array}$ & $\begin{array}{l}48.2 \\
(1.9)\end{array}$ & $\begin{array}{l}138.5 \\
(4.5)\end{array}$ \\
\hline $\begin{array}{l}\text { Sertrali } \\
\text { ne }\end{array}$ & $\begin{array}{l}58.4 \\
(6.5)\end{array}$ & $\begin{array}{l}74.3 \\
(7.6)\end{array}$ & $96.4(9.0)$ & $\begin{array}{l}150.7^{a} \\
(12.5)\end{array}$ & $\begin{array}{l}235.6 \\
(20.4)\end{array}$ & $\begin{array}{l}28.5 \\
(3.0)\end{array}$ & $\begin{array}{l}34.7 \\
(3.4)\end{array}$ & $\begin{array}{l}42.9 \\
(3.9)\end{array}$ & $\begin{array}{l}61.8 \\
(4.9)\end{array}$ & $88.9(6.6)$ \\
\hline $\begin{array}{l}\text { Paroxet } \\
\text { ine }\end{array}$ & $\begin{array}{l}227.1 \\
(25.5)\end{array}$ & $\begin{array}{l}293.9 \\
(29.9)\end{array}$ & $\begin{array}{l}388.9 \\
(35.9)\end{array}$ & $\begin{array}{l}627.6^{a} \\
(51.0)\end{array}$ & $\begin{array}{l}1012.8 \\
(86.2)\end{array}$ & $\begin{array}{l}38.3 \\
(4.0)\end{array}$ & $\begin{array}{l}51.3 \\
(4.7)\end{array}$ & $\begin{array}{l}70.4 \\
(5.7)\end{array}$ & $\begin{array}{c}121.1^{\mathrm{a}} \\
(8.0)\end{array}$ & $\begin{array}{l}208.4 \\
(12.3)\end{array}$ \\
\hline $\begin{array}{l}\text { Duloxet } \\
\text { ine }\end{array}$ & $\begin{array}{l}68.8 \\
(8.0)\end{array}$ & $\begin{array}{l}105.8 \\
(10.4)\end{array}$ & $\begin{array}{l}168.7 \\
(14.0)\end{array}$ & $\begin{array}{c}374.7^{a} \\
(24.9)\end{array}$ & $\begin{array}{l}832.0 \\
(58.6)\end{array}$ & $0.7(0.1)$ & $\begin{array}{c}0.9 \\
(0.09)\end{array}$ & $1.2(0.1)$ & $1.9^{\mathrm{a}}(0.1)$ & $3.1(0.2)$ \\
\hline $\begin{array}{l}\text { Venlafa } \\
\text { xine }\end{array}$ & $\begin{array}{c}5.7 \times 10^{3} \\
(600.4)\end{array}$ & $\begin{array}{c}9.8 \times 10^{3} \\
(850.3)\end{array}$ & $\begin{array}{c}17.4 \times 10^{3} \\
(1260.2)\end{array}$ & $\begin{array}{c}47.6 \times 10^{3} \\
(2680.3)\end{array}$ & $\begin{array}{c}132.4 \times 10^{3} \\
(8294.8)\end{array}$ & $\begin{array}{c}1.7 \times 10^{3} \\
(160.1)\end{array}$ & $\begin{array}{c}2.4 \times 10^{3} \\
(200.1)\end{array}$ & $\begin{array}{c}3.5 \times 10^{3} \\
(256.8)\end{array}$ & $\begin{array}{c}6.9 \times 10^{3} \\
(407.4)\end{array}$ & $\begin{array}{c}13.5 \times 10^{3} \\
(737.6)\end{array}$ \\
\hline $\begin{array}{l}\text { Clomipr } \\
\text { amine }\end{array}$ & $\begin{array}{c}95.4 \\
(10.7)\end{array}$ & $\begin{array}{l}141.8 \\
(13.8)\end{array}$ & $\begin{array}{l}218.1 \\
(18.2)\end{array}$ & $\begin{array}{l}455.5^{a} \\
(31.3)\end{array}$ & $\begin{array}{l}951.1 \\
(70.2)\end{array}$ & $1.8(0.2)$ & $2.0(0.2)$ & $2.5(0.2)$ & $3.3(0.3)$ & $4.4(0.4)$ \\
\hline $\begin{array}{l}\text { Amitrity } \\
\text { line }\end{array}$ & $\begin{array}{l}211.6 \\
(23.8)\end{array}$ & $\begin{array}{l}288.3 \\
(28.8)\end{array}$ & $\begin{array}{l}403.7 \\
(35.9)\end{array}$ & $\begin{array}{l}714.9^{a} \\
(54.6)\end{array}$ & $\begin{array}{l}1268.0 \\
(102.4)\end{array}$ & $\begin{array}{l}15.8 \\
(1.7)\end{array}$ & $\begin{array}{l}20.4 \\
(1.9)\end{array}$ & $\begin{array}{l}27.1 \\
(2.3)\end{array}$ & $\begin{array}{l}43.8^{\mathrm{a}} \\
(3.1)\end{array}$ & $70.9(4.5)$ \\
\hline $\begin{array}{l}\text { Citalopr } \\
\text { am }\end{array}$ & $\begin{array}{l}405.9 \\
(46.0)\end{array}$ & $\begin{array}{l}727.2 \\
(66.2)\end{array}$ & $\begin{array}{l}1369.4 \\
(100.2)\end{array}$ & $\begin{array}{l}4039.8 \\
(221.4)\end{array}$ & $\begin{array}{c}11918.4 \\
(725.4)\end{array}$ & $\begin{array}{l}213.2 \\
(22.2)\end{array}$ & $\begin{array}{l}264.7 \\
(25.2)\end{array}$ & $\begin{array}{l}334.7 \\
(29.1)\end{array}$ & $\begin{array}{l}499.8 \\
(38.0)\end{array}$ & $\begin{array}{l}746.4 \\
(52.8)\end{array}$ \\
\hline
\end{tabular}

a from Minguez et al (2016) 
Table 3. Predicted toxic units (TU) following Concentration Addition model and experimental TUs define for each antidepressant as the ratio between its observed $\mathrm{IC}_{20}$ in mixture and its $\mathrm{IC}_{20}$ when alone, for Raphidocelis subcapitata (A) and Skeletonema marinoi (B). Shift from simple additive effects is calculated as: 1 - (Experimental $T_{i} /$ Predicted $\left.T U_{i}\right)$, when CA is rejected (i.e. for STU < 0.8: synergistic effects and, STU > 1.2: antagonistic effects). Positive shifts mean that compounds are more toxic in mixture than expected, and inversely in the case of negative shifts.

\begin{tabular}{|c|c|c|c|c|c|c|}
\hline \multirow[t]{2}{*}{$\begin{array}{l}\text { A. Raphidoce } \\
\text { subcapitata }\end{array}$} & \multicolumn{2}{|c|}{ Mixture 9 compounds } & \multicolumn{2}{|c|}{ Mixture Amines I / II } & \multicolumn{2}{|c|}{ Mixture Amines III } \\
\hline & $\begin{array}{c}\text { Predicted } \\
\text { TU }_{i}\end{array}$ & $\begin{array}{c}\text { Experimental } \\
T_{\mathrm{i}}\end{array}$ & $\begin{array}{c}\text { Predicted } \\
\text { TU }_{i}\end{array}$ & $\begin{array}{c}\text { Experimental } \\
T_{U_{i}}\end{array}$ & $\begin{array}{c}\text { Predicted } \\
\text { TU }_{i} \\
\end{array}$ & $\begin{array}{c}\text { Experimental } \\
\mathrm{TU}_{\mathrm{i}}\end{array}$ \\
\hline Fluvoxamine & 0.111 & $\begin{array}{c}0.086 \\
(+0.218)\end{array}$ & 0.200 & 0.200 & & \\
\hline Fluoxetine & 0.111 & $\begin{array}{c}0.091 \\
(+0.173)\end{array}$ & 0.200 & 0.173 & & \\
\hline Sertraline & 0.111 & $\begin{array}{c}0.094 \\
(+0.145)\end{array}$ & 0.200 & 0.164 & 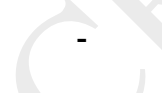 & - \\
\hline Paroxetine & 0.111 & $\begin{array}{c}0.092 \\
(+0.164)\end{array}$ & 0.200 & 0.169 & & - \\
\hline Duloxetine & 0.111 & $\begin{array}{c}0.083 \\
(+0.245) \\
0.072\end{array}$ & 0.200 & & - & - \\
\hline Venlafaxine & 0.111 & $(+0.345)$ & & & 0.250 & 0.299 \\
\hline Clomipramine & 0.111 & $\begin{array}{c}0.084 \\
(+0.236)\end{array}$ & & & 0.250 & 0.231 \\
\hline Amitriptyline & 0.111 & $\begin{array}{c}0.089 \\
(+0.191)\end{array}$ & & & 0.250 & 0.196 \\
\hline Citalopram & 0.111 & $\begin{array}{c}0.073 \\
(+0.336)\end{array}$ & & _ & 0.250 & 0.325 \\
\hline $\mathrm{STU}=\Sigma \mathrm{TU}_{\mathrm{i}}$ & & 0.764 & 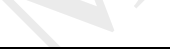 & 0.928 & & 1.051 \\
\hline
\end{tabular}

\section{B. Skeletonema marinoi}

\begin{tabular}{|c|c|c|c|c|c|c|}
\hline \multirow[b]{2}{*}{ Compounds } & \multicolumn{2}{|c|}{ Mixture 9 compounds } & \multicolumn{2}{|c|}{ Mixture Amines I / II } & \multicolumn{2}{|c|}{ Mixture Amines III } \\
\hline & $\begin{array}{c}\text { Predicted } \\
\mathrm{TU}_{\mathrm{i}}\end{array}$ & $\begin{array}{c}\text { Experimental } \\
\mathrm{TU}_{\mathrm{i}}\end{array}$ & $\begin{array}{c}\text { Predicted } \\
\mathrm{TU}_{\mathrm{i}}\end{array}$ & $\begin{array}{c}\text { Experimental } \\
\mathrm{TU}_{\mathrm{i}}\end{array}$ & $\begin{array}{c}\text { Predicted } \\
\mathrm{TU}_{\mathrm{i}}\end{array}$ & $\begin{array}{c}\text { Experimental } \\
T_{\mathrm{i}}\end{array}$ \\
\hline Fluvoxamine & 0.111 & $\begin{array}{c}0.073 \\
(+0.336)\end{array}$ & 0.200 & $\begin{array}{c}0.186 \\
(+0.070)\end{array}$ & 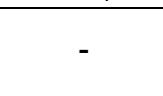 & - \\
\hline Fluoxetine & 0.111 & & 0.200 & $\begin{array}{l}0.462(- \\
1.310)\end{array}$ & - & - \\
\hline Sertraline & 0.111 & $\begin{array}{c}0.079 \\
(+0.282)\end{array}$ & 0.200 & $\begin{array}{c}0.175 \\
(+0.125)\end{array}$ & - & - \\
\hline Paroxetine & 0.111 & $\begin{array}{c}0.066 \\
(+0.400)\end{array}$ & 0.200 & $\begin{array}{l}0.210(- \\
0.050)\end{array}$ & - & - \\
\hline Duloxetine & 0.111 & $\begin{array}{c}0.072 \\
(+0.347)\end{array}$ & 0.200 & $\begin{array}{c}0.193 \\
(+0.035)\end{array}$ & - & - \\
\hline Venlafaxine & 0.111 & $\begin{array}{c}0.059 \\
(+0.463)\end{array}$ & - & - & 0.250 & $\begin{array}{c}0.075 \\
(+0.700)\end{array}$ \\
\hline Clomipramine & 0.111 & $\begin{array}{c}0.089 \\
(+0.189)\end{array}$ & - & - & 0.250 & $\begin{array}{c}0.097 \\
(+0.612)\end{array}$ \\
\hline Amitriptyline & 0.111 & $\begin{array}{c}(+0.364) \\
0.076\end{array}$ & - & - & 0.250 & $\begin{array}{c}0.083 \\
(+0.668)\end{array}$ \\
\hline Citalopram & 0.111 & $\begin{array}{c}0.070 \\
(+0.309)\end{array}$ & - & - & 0.250 & $\begin{array}{c}0.086 \\
(+0.656)\end{array}$ \\
\hline $\mathrm{STU}=\Sigma T \mathrm{TU}_{\mathrm{i}}$ & & 0.624 & & 1.227 & & 0.341 \\
\hline
\end{tabular}

